\title{
White spruce enrichment planting in boreal mixedwoods as influenced by localized site preparation: 11-year update
}

\author{
by Myriam Delmaire ${ }^{1}$, Nelson Thiffault ${ }^{2 *}$, Evelyne Thiffault ${ }^{1}$ and Julie Bouliane ${ }^{3}$
}

\begin{abstract}
Ecosystem-based management aims to maintain the natural proportion of native species over a given landscape. White spruce (Picea glauca (Moench) Voss) is a species sensitive to environmental conditions; it is especially demanding in terms of nutrients and its regeneration is negatively affected by clearcut harvesting. Its proportion is now significantly lower than what it was in the preindustrial forests of Québec (Canada). As a native species in boreal Québec, efforts to maintain its proportion in the landscape are undertaken for white spruce, but little is known about the best practices to maximize establishment success of seedlings planted in the balsam fir (Abies balsamea)-white birch (Betula papyrifera) bioclimatic domain. Our general objective was to identify planting practices as related to microsite treatment that favour white spruce sapling survival and size after 11 growing seasons following enrichment planting of sites harvested by mechanized careful logging in an ecosystem-based management context. We also aimed at comparing white spruce performance with that of black spruce (Picea mariana (Mill.) BSP), a native species that is less sensitive to abiotic stress. Finally, we wanted to assess stand composition at this juvenile stage, as a function of microsite treatment and planted species. Localized site preparation did not significantly affect growth or survival for white spruce compared to control conditions. Furthermore, localized site preparation did not increase the proportion of white and black spruce, as evaluated by basal area. Our results suggest that white spruce can be successfully established in enrichment planting in fir-dominated boreal forests, without site preparation.
\end{abstract}

Keywords: silviculture, boreal forest, ecosystem-based management, site preparation, enrichment planting

\section{RÉSUMÉ}

L'aménagement écosystémique vise le maintien de la proportion naturelle d'essences indigènes dans le paysage. L'épinette blanche (Picea glauca (Moench) Voss) est une essence sensible aux conditions environnementales, particulièrement la disponibilité des éléments nutritifs, et sa régénération naturelle est affectée négativement par le régime des coupes totales. Sa proportion a significativement diminué par rapport à sa proportion historique dans les forêts boréales du Québec (Canada). En tant qu'essence indigène dans cette région, des efforts pour maintenir sa proportion sont entrepris pour la conserver dans le paysage forestier mais peu de connaissances sont disponibles concernant les conditions qui favorisent son succès d'établissement dans le domaine bioclimatique de la sapinière (Abies balsamea) à bouleau blanc (Betula papyrifera). Dans ce contexte, notre objectif général était d'identifier les pratiques de mise en terre qui favorisent la survie et la croissance des gaules d'épinette blanche 11 ans après une plantation d'enrichissement sur un site récolté par coupe avec protection de la régénération et du sol dans un contexte d'aménagement écosystémique. Nous visions également à comparer les performances de l'épinette blanche à celles de l'épinette noire (Picea mariana (Mill.) BSP), une essence indigène moins sensible aux stress abiotiques. Enfin, nous voulions évaluer la composition du peuplement à ce stade juvénile, en réponse au traitement de microsite et aux essences plantées. La préparation localisée du sol n’a pas eu d'effet significatif sur la croissance ou la survie de l'épinette blanche par rapport aux témoins. De plus, la préparation localisée du sol n'a pas augmenté la proportion de l'épinette blanche et de l'épinette noire, telle qu'évaluée par la surface terrière. Nos résultats suggèrent qu'en sapinière boréale, l'épinette blanche peut s'établir avec succès dans un traitement de plantation d'enrichissement, sans préparation de terrain.

Mots-clés : sylviculture, forêt boréale, aménagement écosystémique, préparation de terrain, enrichissement

\footnotetext{
${ }_{1}^{1}$ Département des sciences du bois et de la forêt, Université Laval, 2405 rue de la Terrasse, Québec, QC, G1V 0A6, Canada ${ }^{2}$ Canadian Wood Fibre Centre, Natural Ressources Canada, 1055 du P.E.P.S., P.O. Box 10380, Sainte-Foy Stn., Québec, QC, G1V 4C7, Canada.* Corresponding author: nelson.thiffault@canada.ca

${ }^{3}$ Direction du soutien à la gestion du régime forestier, Ministère des Forêts, de la Faune et des Parcs du Québec, 5700, 4e Avenue Ouest, Québec, QC, G1H 6R1, Canada.
} 


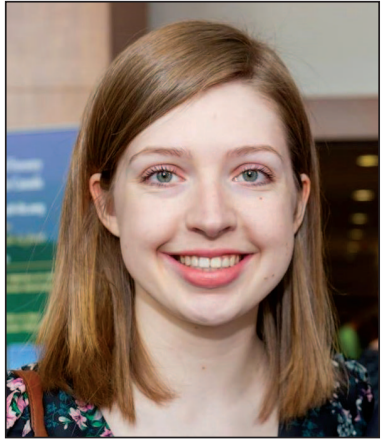

Myriam Delmaire

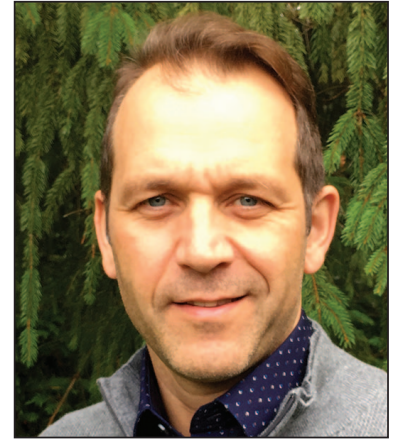

Nelson Thiffault

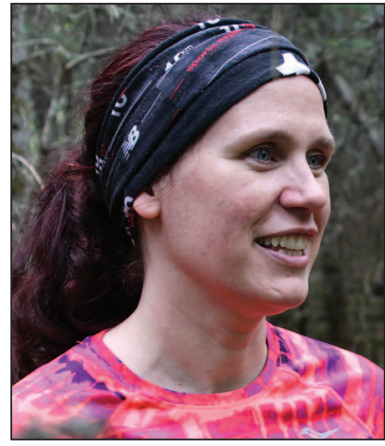

Evelyne Thiffault

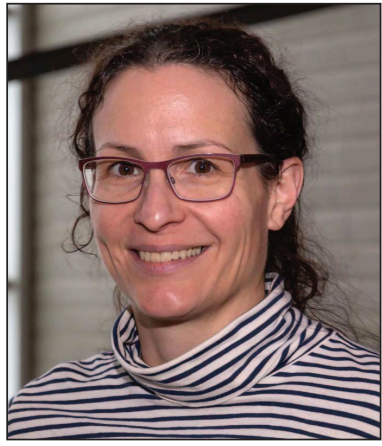

Julie Bouliane

\section{Introduction}

An increasing number of anthropogenic factors, such as harvesting, are modifying the structure and composition of ecosystems (Millar et al. 2007). Because of the long life span of trees, forest ecosystems do not adapt rapidly to environmental changes (Lindner et al. 2010). Whereas ecosystembased management has become the dominant management strategy in northern America, being considered as an efficient means to preserve both biodiversity and a sustainable fiber supply (Perera et al. 2004), it is uncertain if this paradigm will ensure a sustained provision of ecosystem services, especially under a changing climate (Brang et al. 2014; Boulanger et al. 2019).

In boreal and sub-boreal ecosystems of Canada, white spruce (Picea glauca (Moench) Voss.) is an example of a species sensitive to environmental conditions; it is especially demanding in terms of nutrients (Quesnel and Côté 2009). The species shows dieback syndrome such as needle chlorosis and defoliation, a phenomenon expected to be worsened by climate change, especially in regions characterized by low base cation availability (Ouimet et al. 2013). Furthermore, white spruce natural regeneration is limited, as seedling survival is related to the presence of decaying logs (Simard et al. 2003), a structural feature that often is reduced by forest management (Freedman et al. 1996; Senez-Gagnon et al. 2018). Moreover, the species does not build seed or seedling banks (Greene et al. 1999).

Efforts to increase the proportion of white spruce in balsam fir (Abies balsamea (L.) Mill.) ecosystems are undertaken in eastern Canada. However, many plantation projects show chlorosis symptoms and stunted growth for spruce in these ecosystems (St-Hilaire 2011). In boreal stands, mechanical site preparation usually benefits tree establishment by disturbing the organic layer, exposing the mineral soil, thus favouring better access to soil water, increasing root zone temperatures, increasing decomposition, and creating competition-free microsites (Löf et al. 2012). However, longerterm benefits of site preparation are not always observed, especially on sites characterized by thin humus layers (Thiffault and Ward 2018). While short-term experimental results have confirmed the potential of localized site preparation followed by enrichment planting to increase white spruce stocking in areas harvested with careful logging around advanced growth (Thiffault et al. 2013), no study has yet documented the longer-term establishment success of this species under this silviculture scenario. Planting depth, i.e., the relative positioning of the root-collar relative to the organic-mineral interface, also has the potential to influence plantation success. Deeply planted spruce seedlings tends to form adventitious roots at the base of the stems, with positive impacts on nutrition and physiology (Pernot et al. 2019).

In this context, our general objective was to identify planting practices that maximize white spruce sapling survival and size as measured 11 growing seasons after enrichment planting on sites harvested by careful mechanized logging in the boreal mixedwoods of Québec (Canada). We also aimed at comparing white spruce performance with that of black spruce (Picea mariana (Mill.) BSP), a native species that is less sensitive to abiotic stress (Lamhamedi and Bernier 1994) and that is considered for replacing white spruce in plantation strategies due to uncertainties related to long-term survival of the latter. Finally, we wanted to assess stand composition at this juvenile stage as a function of microsite treatment and planted species. Because of their different inherent sensitivity to environmental stress, we first predicted that planted black spruce saplings would perform better in terms of survival, height and diameter than planted white spruce. Based on short-term results (Thiffault et al. 2013), we expected that localized site preparation would have small or insignificant effects on planted seedling survival and growth for both species, as compared to planting without site preparation. Further, we expected that seedlings planted with the root collar at the organic-mineral interface would perform better than those planted with the root collar at the soil surface. As a result, we finally posited that localized site preparation would not significantly influence forest composition after 11 years. However, due to increased survival and growth, spruce proportion was expected to be higher in plots where seedlings were planted with the root collar at the organic-mineral interface compared to those for which seedlings were planted with the root collar at the soil surface.

\section{Materials and methods \\ Study area}

We conducted an experiment in the Montmorency Forest $\left(71^{\circ} 08^{\prime} 50^{\prime \prime} \mathrm{W}, 47^{\circ} 19^{\prime} 20^{\prime \prime} \mathrm{N}\right)$, about $75 \mathrm{~km}$ north of Quebec City, Canada (Fig. 1a). The region is located within the balsam fir - paper birch (Betula papyrifera Marsh.) bioclimatic domain described by Saucier et al. (2009). Climate is subpolar-subhumid continental and the mean annual temperature 

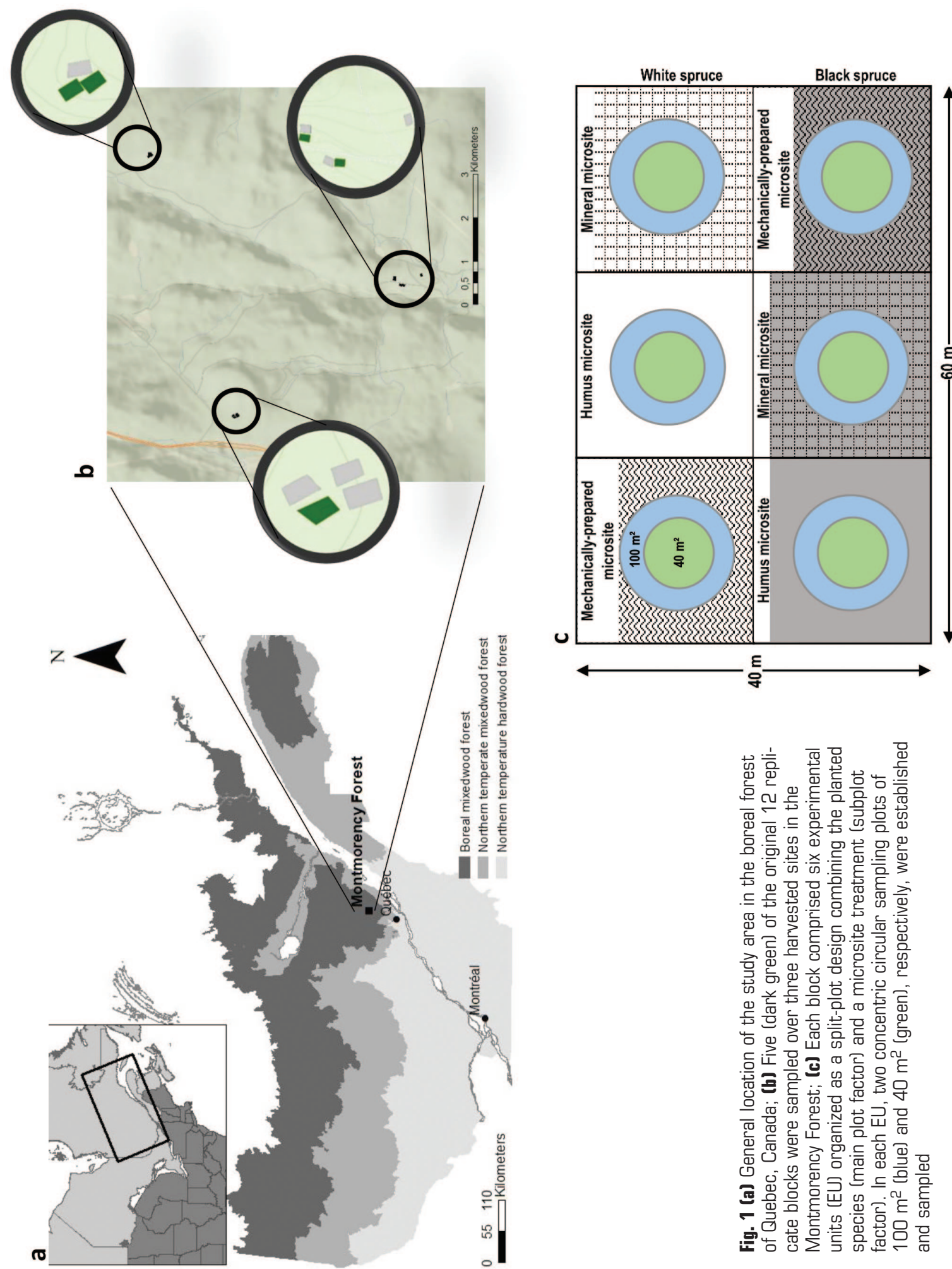
is $0{ }^{\circ} \mathrm{C}$. Mean annual precipitation is $1175 \mathrm{~mm}$, of which $40 \%$ falls as snow (Saucier et al. 2009). Most soils are classified as ferro-humic podzols with LFH organic layers classified as mor with a thickness of $5-10 \mathrm{~cm}$. The experiment was distributed over three sites located within $6 \mathrm{~km}$ from each other, and originally dominated by mature balsam fir stands (Fig. 1b). The sites were clearcut-harvested by careful mechanized logging between 2006 and 2008. At the time of planting (see below), sites were dominated by dense balsam fir regeneration (6 500 stem/ha; Thiffault et al. 2013). Some areas were gradually invaded by Prunus pensylvanica L. and Rubus idaeus L., which were later reduced by heavy browsing by moose (Alces alces L.). Oxalis montana Raf., Cornus canadensis L., Trientalis borealis Raf. and Sphagnum spp. characterized the understory layer.

\section{Experimental design and treatments}

In June 2008, we established a complete block split-plot design with 12 replicate blocks distributed over the three harvested sites on which natural advance regeneration was already present (four blocks at each location; see Thiffault et al. (2013) for details) (Fig. 1b). Each block measured $40 \mathrm{~m} \times$ $60 \mathrm{~m}$ and was divided into two main plots of $20 \mathrm{~m} \times 60 \mathrm{~m}$ that were randomly assigned to be planted with either white spruce or black spruce (Fig. 1c). We divided the main plots into three subplots $(20 \mathrm{~m} \times 20 \mathrm{~m})$ that randomly received one of the three following microsite treatments: forest floor planting with seedling root-plug inserted into the organic LFH layers and the root-collar placed at the humus surface, and with minimal humus disturbance (further referred to as humus microsites: $\mathrm{H}$ ); mineral soil planting, with the seedling rootplug completely inserted into the mineral soil, i.e., the rootcollar placed at the organic - mineral interface, with minimal humus disturbance (further referred to as mineral microsites: $\mathrm{M})$; and planting on a mechanically-prepared microsite (MSP). For the MSP treatment, a brush saw equipped with a manufactured head designed to mix the humus layer with the first $5-10 \mathrm{~cm}$ of mineral soil was manually operated. The diameter of the resulting microsites was $\sim 40 \mathrm{~cm}$.

Seedlings were obtained from tree nurseries located in StProsper, Québec (white spruce) and Grandes-Piles, Québec (black spruce). They were produced from local seed sources in $200 \mathrm{~cm}^{3}$ containers and averaged $52.7 \mathrm{~cm} \pm 6.5$ and 47.6 $\mathrm{cm} \pm 3.3$ in height for white spruce and black spruce, respectively. Enrichment planting with the objective of complementing natural regeneration was performed at a density of 1 000 seedlings $\mathrm{ha}^{-1}$, i.e., at an approximate spacing of $3 \mathrm{~m} \times 3$ $\mathrm{m}$. After planting, each seedling was identified with a permanent metal rod and tag to allow long-term measurements at the tree level.

\section{Sapling measurements}

To test our hypotheses, in October 2018 (11 growing seasons after planting) we selected five blocks from the original 12 replicates and established two concentric circular sampling plots in the centre of each subplot (Fig. 1c). The largest circular sampling plot covered $100 \mathrm{~m}^{2}$ (radius $=5.64 \mathrm{~m}$ ). In this sampling plot, we measured the height and diameter at breast height (dbh; at $1.3 \mathrm{~m}$ ) of all living planted trees. For each tree, we evaluated chlorosis visually using a six-class system (Table 1 ). The metal rods and tags were used to assess mortality for trees that could not be found. Using height and dhb values, we calculated a volume index for individual planted trees using the formula for a cone. The smallest circular sampling plot covered $40 \mathrm{~m}^{2}$ (radius $=3.67 \mathrm{~m}$ ). In this plot, we identified the species and tallied every tree with a dbh $\geq 1.1 \mathrm{~cm}$ using 2-cm dbh classes. Diameter data from the small sampling plot was used to calculate stand level basal area by species and group of species (conifer, deciduous).

\section{Statistical analyses}

To test for effects of species microsite, and their interaction on response variables, we fit mixed effect models using the lme4 (Bates et al. 2015) package in the R computing environment v3.5.1 (R Core Team 2013). We used LmerTest (Kuznetsova et al. 2017) to obtain mixed model p-values. At the tree level, we evaluated species microsite, and species $\times$ microsite fixed effects on height and dbh. For survival, we specified a binomial distribution with a logit link. At the stand level, we evaluated species microsite, and species $\times$ microsite fixed effects on total basal area and spruce basal area, and calculated the proportion of basal area by group of species. For all analyses, we considered blocks and interactions with blocks as random effects and we deemed that treatments, species and interaction effects were significant at $\alpha=0.05$. Data were verified for ANOVA prerequisites; homoscedasticity and normality were tested using standard graphical procedures. Diameter at breast height and total basal area were square root transformed prior to analyses to respect normality and homoscedasticity prerequisites; we present data on their original, untransformed scales.

\section{Results}

\section{Tree level responses}

After 11 growing seasons, height and dbh of the planted spruce did not differ between species or microsite treatment (Table 2). Saplings averaged $295 \mathrm{~cm}$ in height and $34 \mathrm{~mm}$ in dbh (Fig. 2). Similarly, we did not detect any microsite treatment or species effect on sapling survival (Table 2), which averaged $84 \%$ after 11 growing seasons across microsite types and species. Chlorosis affected $34 \%$ of the white spruce saplings at the stage 1 or 2 (Table 1); none of the white spruce were affected further than stage 2 . We did not observe any chlorosis on planted black spruce.

\section{Stand level responses}

Total basal area was not significantly influenced by species or microsite treatments (Table 3). Basal area of spruce saplings averaged $0.25 \mathrm{~m}^{2} / \mathrm{ha}$, and was significantly influenced by species, but not by microsite. Spruce basal area was 0.02 $\mathrm{m}^{2} /$ ha higher in plots planted with white spruce compared to plots planted with black spruce (Table 3; Fig. 3).

\section{Discussion}

We predicted that planted black spruce saplings would perform better, in terms of survival, height and diameter, then planted white spruce. After 11 growing seasons, we did not observe significant differences between the two species, although we observed significant signs of chlorosis on white spruce. It thus appears that at this juvenile stage, the nutritional and climate sensitivity of white spruce (Quesnel and Côté 2009; Ouimet et al. 2013) has yet to influence the species 
Table 1. Description of the 6-class system used to evaluate chlorosis of white spruce (Picea glauca) and black spruce (P. mariana) saplings, as influenced by species and microsite treatments 11 growing seasons after planting in boreal mixedwoods of Québec, Canada

\begin{tabular}{lll}
\hline Class Description & Illustration \\
\hline
\end{tabular}

$0 \quad$ No sign of chlorosis; healthy tree

$1 \quad$ Presence of chlorosis, but minimal. Needles are slightly turning yellow; there is no loss of needles and no colour gradient
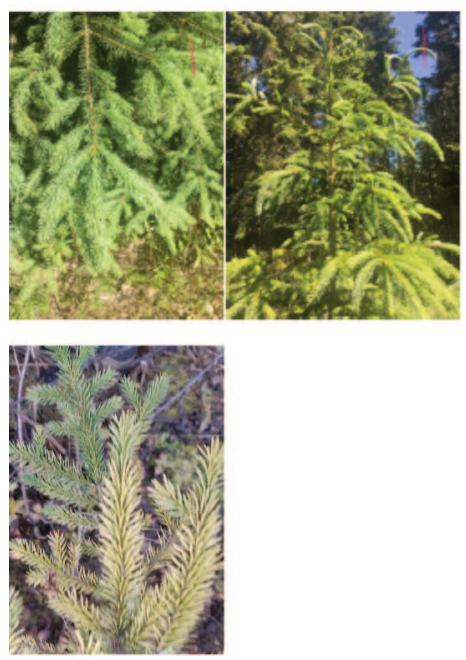

$2 \quad$ Current-year and one-year old needles are green or slightly yellow, older needles are yellow or red and treetop is entirely alive. Presence of colour gradient

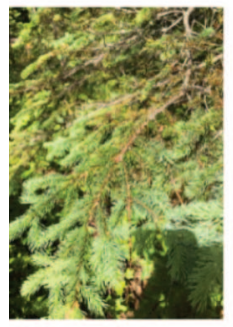

3 Part of current-year needles are yellow or red, major part of the older needles are yellow or red and treetop is partly in decline

Most of current-year needles are yellow or red, older needles are almost all dead or have fallen, treetop is mainly in decline
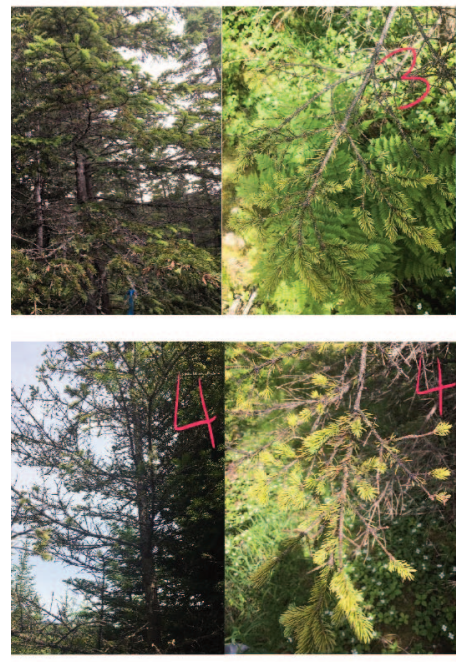

$5 \quad$ The tree is dead

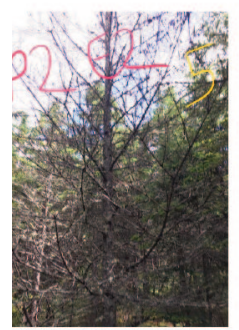


Table 2. ANOVA results for white spruce (Picea glauca) and black spruce ( $P$. mariana) dimensions and survival as influenced by species and microsite treatment, 11 growing seasons after planting in boreal mixedwoods of Québec, Canada

\begin{tabular}{|c|c|c|c|c|c|c|c|c|c|c|}
\hline \multirow[b]{2}{*}{ Effect (fixed) } & \multicolumn{4}{|c|}{ Height } & \multicolumn{3}{|c|}{$\mathrm{dbh}^{*}$} & \multicolumn{3}{|c|}{ Survival } \\
\hline & ndf & ddf & $F$ & $P$ value & ddf & $F$ & $P$ value & ddf & $F$ & $P$ value \\
\hline Species (S) & 1 & 4.1 & 0.47 & 0.531 & 4.1 & 0.22 & 0.666 & 4 & 5.28 & 0.099 \\
\hline Microsite (M) & 2 & 14.7 & 1.55 & 0.246 & 14.5 & 0.72 & 0.505 & 16 & 0.26 & 0.537 \\
\hline $\mathrm{S} \times \mathrm{M}$ & 2 & 14.7 & 0.10 & 0.908 & 14.5 & 0.03 & 0.974 & 16 & 0.17 & 0.643 \\
\hline
\end{tabular}

ndf: numerator degrees of freedom, ddf: denominator degrees of freedom, dbh: diameter at breast height. ndf were similar for all variables. ddf were calculated using the Satterthwaite method (Spilke et al. 2005). ${ }^{*}$ Analyses performed on square-root transformed data
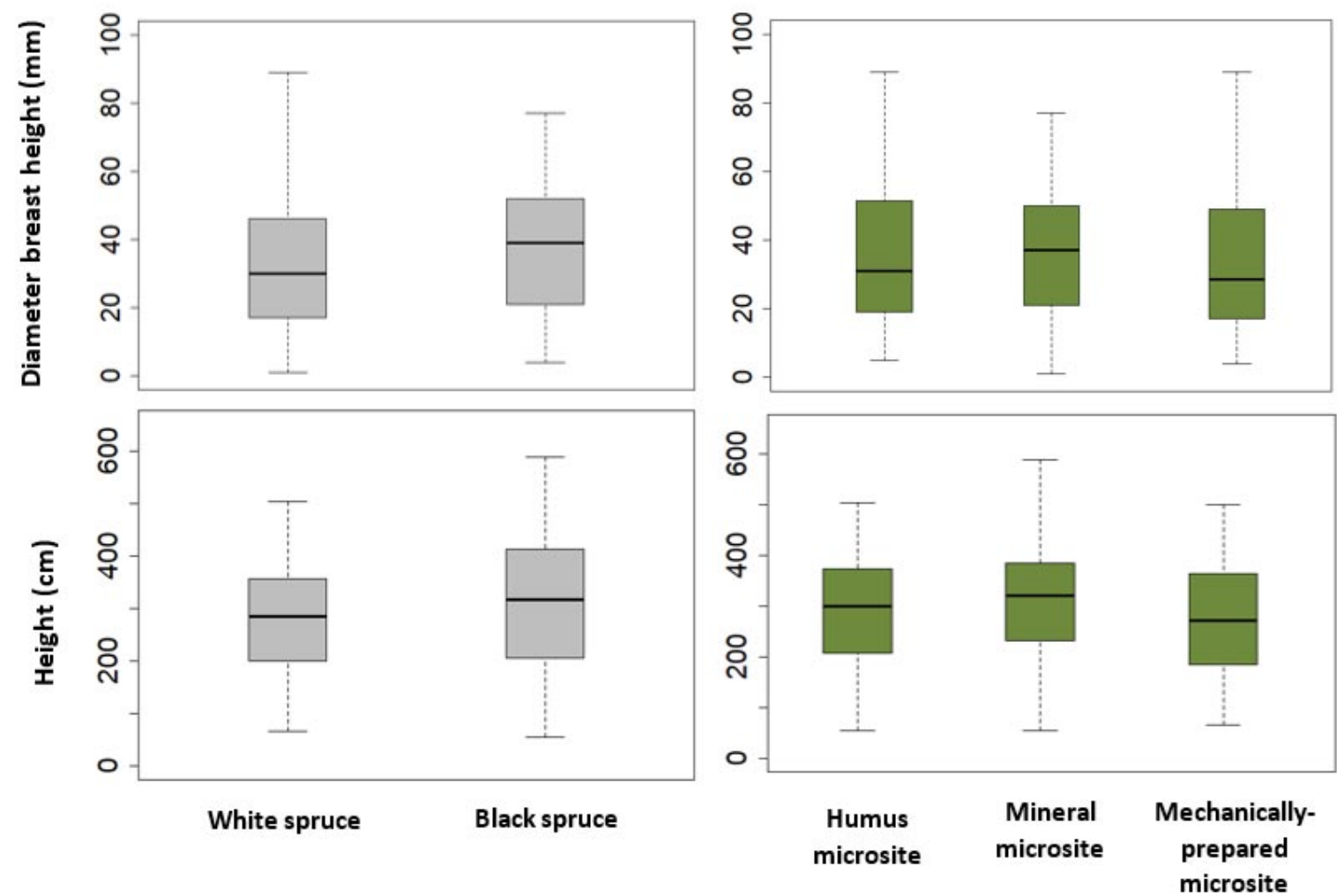

Fig. 2 Species and microsite treatment effects on diameter at breast height (at $1.3 \mathrm{~m}$ ) and height of planted white spruce (Picea glaucal and black spruce (P. mariana), 11 growing seasons after planting on boreal sites of Quebec, Canada

performance, compared to black spruce. Based on landscape scale observations that show that about $2 / 3$ of white spruce planted between 1994 and 1998 in the region exhibited stunted growth after 9-13 years (St-Hilaire 2011), we expect chlorosis and reduced growth to become more generalized and severe within the next decade. This could start influencing growth and eventually cause increased mortality for planted white spruce, compared to black spruce. Longerterm monitoring will be needed to verify this prediction.

Microsite treatment did not have a significant effect on seedling growth and physiology in the short-term (Thiffault et al. 2013). Hence, we did not expect the treatment to have significant effects after 11 years. However, site preparation effects can be dynamic and appear over time. For example, small but non-significant increases in seedling dimensions and foliar biomass can result in a positive feedback loop effect through litter accumulation, which in turn increases nutrient availability and promotes growth (Moroni et al. 2009). We did not expect localized site preparation to benefit planted seedling survival and growth for either species, as compared to direct planting either with the root collar placed at the organic-mineral interface or at the humus surface. Indeed, 
Table 3. ANOVA results for the basal area of white spruce (Picea glauca) and black spruce ( $P$. mariana) planted plots as influenced by species and microsite treatment, 11 growing seasons after planting in boreal mixedwoods of Québec, Canada

\begin{tabular}{|c|c|c|c|c|c|c|c|}
\hline \multirow[b]{2}{*}{ Effect (fixed) } & \multicolumn{4}{|c|}{ Total basal area ${ }^{\star}$} & \multicolumn{3}{|c|}{ Spruce basal area } \\
\hline & ndf & ddf & $F$ & $P$ value & ddf & $F$ & $P$ value \\
\hline Species (S) & 1 & 4 & 0.52 & 0.511 & 4 & 13.55 & 0.021 \\
\hline Microsite (M) & 2 & 16 & 0.79 & 0.471 & 16 & 1.17 & 0.337 \\
\hline $\mathrm{S} \times \mathrm{M}$ & 2 & 16 & 0.45 & 0.647 & 16 & 1.22 & 0.322 \\
\hline
\end{tabular}

ndf: numerator degrees of freedom, ddf: denominator degrees of freedom. Total basal area includes all naturally established and planted trees with a diameter at breast height $\geq 1.1 \mathrm{~cm}$. ndf were similar for all variables. ddf were calculated using Satterthwaite method (Spilke et al. 2005). ${ }^{\star}$ Analyses were performed on square-root transformed data

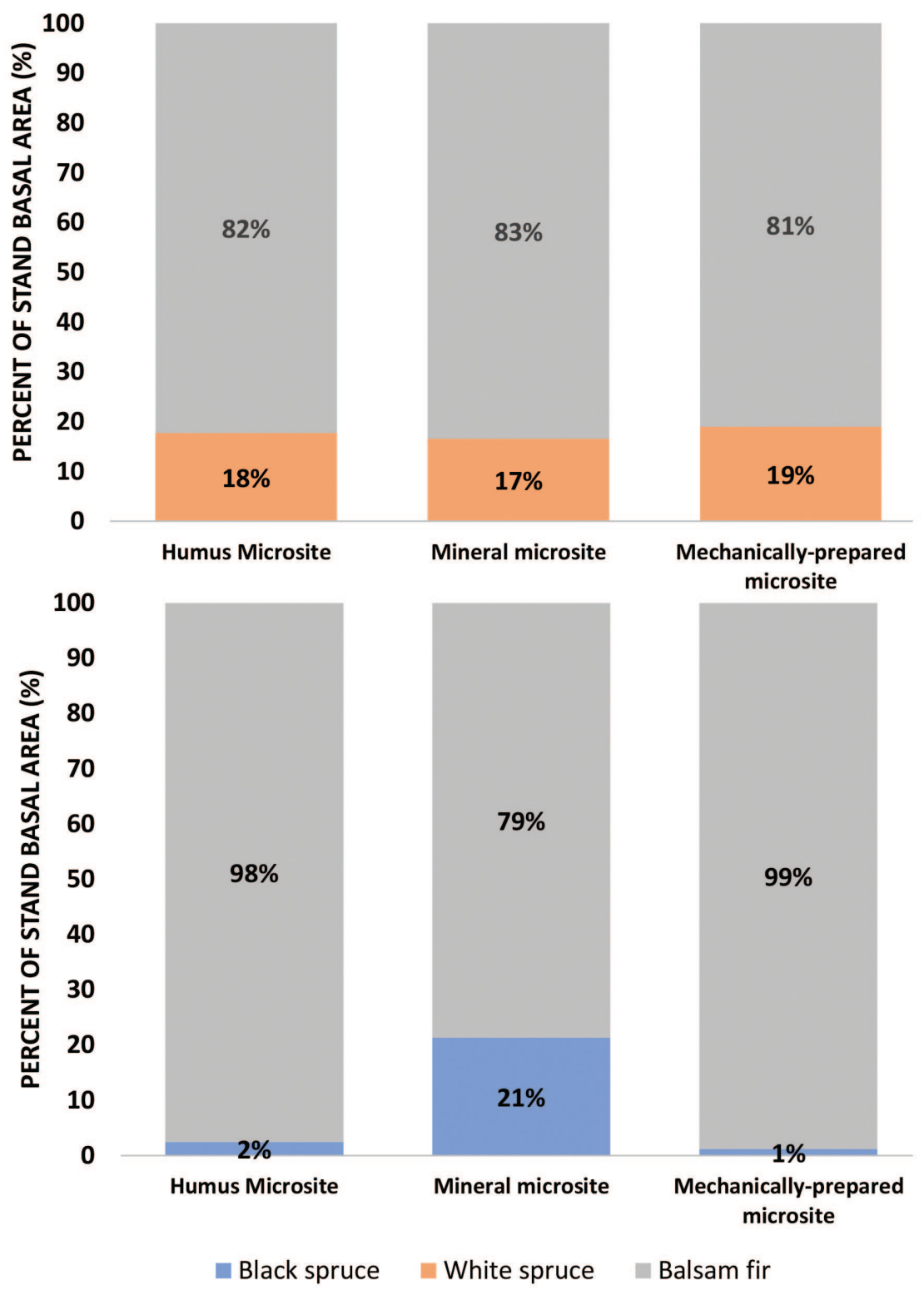

Fig. 3 Percent distribution of basal area across species as influenced by microsite treatments, 11 growing seasons after planting white spruce (Picea glauca) and black spruce (P. mariana) on boreal sites of Quebec, Canada 
the microsite treatment did not influence survival and growth at the sapling stage. We suspect that the localized nature of the site preparation treatment, carried out with a brush saw that might not have created a sufficient mixing effect, used in this context to complement natural balsam fir regeneration with spruce (enrichment planting) rather than replacing it, did not modify the growing environment sufficiently to influence growth. Moreover, in this ecosystem, the humus layer is relatively thin (around 5-10 cm) compared to other northern ecosystems with thick humus layers (around $25-30 \mathrm{~cm}$ ) where site preparation has proven beneficial (e.g., Thiffault and Jobidon 2006; Prévost and Dumais 2018). This, combined with the absence of ericaceous species on these sites (Thiffault et al. 2005), might explain the lack of treatment effect on the planted seedlings (Macdonald et al. 1998; Thiffault et al. 2003). Further, we expected that seedlings planted with the root collar at the organic-mineral interface would perform better than those planted with the root collar at the soil surface. Planting seedlings deeper has indeed proved beneficial to stimulate adventitious root production, with positive impacts on nutrient uptake, particularly nitrogen (Pernot et al. 2019). However, long-term benefits of this practice are not necessarily observed (Paquette et al. 2011), as was the case in our study.

Finally, we hypothesized that deeper planting would significantly influence forest composition after 11 years, increasing the proportion of spruce relative to naturally regenerated species, compared to planting without site preparation. The proportion of spruce basal area to total basal area was not significantly different between planting with or without site preparation or between deep or shallow planting. Our study exemplifies balsam fir resilience in spruce plantations (cf. Fig. 3), as a result of their effective regeneration process (Barrette et al. 2019). Basal area was, however, significantly different between white spruce-planted and black spruce-planted plots. Although being statistically significant, the $0.02 \mathrm{~m}^{2} / \mathrm{ha}$ difference does not have practical impacts for silviculture at this stage of stand development. Longer-term monitoring will be necessary to confirm if the difference in spruce basal area will increase as a function of the planted species.

Our general objective was to identify planting practices that maximize white spruce sapling survival and size after 11 growing seasons following enrichment planting of sites harvested by mechanized careful logging. Overall, our study confirms the potential of enrichment planting after harvesting without site preparation. It also shows that after 11 years of growth, vegetation composition between prepared sites and control plots converges. We thus conclude that localized site preparation is not needed for enrichment planting of white spruce in ecosystems similar to the ones we have studied. Chlorosis is generally reported to appear $10-15$ years after planting for white spruce in this region (St-Hilaire 2011). After eleven years of growth, we observed minimal chlorosis, at levels that did not significantly affect seedling growth and survival, compared to black spruce. These observations further stress the importance of continuous monitoring of this ecosystem over the long-term to assess the causes and impact of chlorosis on tree growth at more advanced stages and identify relevant solutions in silvicultural strategies.

\section{Acknowledgments}

We are indebted to Emma Côté, Thibault Ali-Mehenni, Claire Vredenbregt and Celine Van Puyvelde for their help in field work. The experimental design was established in 2008 with funding from the Fonds de Recherche du Québec Nature et Technologies (formerly the Fonds québécois de la recherche sur la nature et les technologies) awarded to Dr. Louis Bélanger. The recent assessment reported in this study was supported by Laval University (research funds to E. Thiffault) and the Canadian Wood Fibre Centre of Natural Resources Canada (research funds to N. Thiffault). This article is adapted from the bachelor thesis of the lead author.

\section{References}

Barrette, M., N. Thiffault, J.-P. Tremblay and I. Auger. 2019. Balsam fir stands of northeastern North America are resilient to spruce plantation. For. Ecol. Manage. 450: 117504. doi: 10.1016/j.foreco. 2019.117504.

Bates, D., M. Mächler, B.M. Bolker and S.C. Walker. 2015. Fitting linear mixed-effects models using lme4. J. Stat. Soft. 67(1): 1-48. doi: 10.18637/jss.v067.i01.

Boulanger, Y., A. Arseneault, Y. Boucher, S. Gauthier, D. Cyr, A.R. Taylor, D.T. Price and S. Dupuis. 2019. Climate change will affect the ability of forest management to reduce gaps between current and presettlement forest composition in southeastern Canada. Lands. Ecol. 34(1): 159-174. doi: 10.1007/s10980-018-0761-6.

Brang, P., P. Spathelf, J.B. Larsen, J. Bauhus, A. Boncina, C. Chauvin, L. Drössler, C. Garcia-Güiemes, C. Heiri, G. Kerr, M.J. Lexer, B. Mason, F. Mohren, U. Mühlethaler, S. Nocentini, and M. Svoboda. 2014. Suitability of close-to-nature silviculture for adapting temperate European forests to climate change. Forestry 87(4): 492-503. doi: 10.1093/forestry/cpu018.

Freedman, B., V. Zelazny, D. Beaudette, T. Fleming, G. Johnson, S. Flemming, J.S. Gerrow, G. Forbes and S. Woodley. 1996. Biodiversity implications of changes in the quantity of dead organic matter in managed forests. Environ. Rev. 4(3): 238-265. doi: 10.1139/a96-013. Greene, D.F., J.C. Zasada, L. Sirois, D.D. Kneeshaw, H. Morin, I. Charron and M.-J. Simard. 1999. A review of the regeneration dynamics of North American boreal forest tree species. Can. J. For. Res. 29(6): 824-839. doi: 10.1139/x98-112.

Kuznetsova, A., P.B. Brockhoff and R.H.B. Christensen. 2017. lmerTest Package: Tests in Linear Mixed Effects Models. J. Stat. Soft. 82(13): 1-26. doi:10.18637/jss.v082.i13.

Lamhamedi M.S. and P.Y. Bernier. 1994. Ecophysiology and field performance of black spruce (Picea mariana): A review. Ann. Sci. For. 51(6): 529-551. doi: 10.1051/forest:19940601.

Lindner, M., M. Maroschek, S. Netherer, A. Kremer, A. Barbati, J. Garcia-Gonzalo, R. Seidl, S. Delzon, P. Corona, M. Kolström, M.J. Lexer and M. Marchetti. 2010. Climate change impacts, adaptive capacity, and vulnerability of European forest ecosystems. For. Ecol. Manage. 259(4): 698-709. doi: 10.1016/j.foreco.2009.09.023.

Löf, M., D.C. Dey, R.M. Navarro and D.F. Jacobs. 2012. Mechanical site preparation for forest restoration. New For. 43(5-6): 825848. doi: 10.1007/s11056-012-9332-x.

Macdonald, S.E., M.G. Schmidt and R.L. Rothwell. 1998. Impacts of mechanical site preparation on foliar nutrients of planted white spruce seedlings on mixed-wood boreal forest sites in Alberta. For. Ecol. Manage. 110(1-3): 35-48. doi: 10.1016/S0378-1127(98)00272-2. Millar, C.I., N.L. Stephenson and S.L. Stephens. 2007. Change and forests of the future: Managing in the face of uncertainty. Ecol. Appl. 17(8): 2145-2151. doi: 10.1890/06-1715.1.

Moroni, M.T., N. Thiffault, B.D. Titus, C. Mante and F. Makeschin. 2009. Controlling Kalmia and reestablishing conifer dominance enhances soil fertility indicators in central Newfoundland, Canada. Can. J. For. Res. 39(7): 1270-1279. doi: 10.1139/X09-061. 
Ouimet, R., J.-D. Moore, L. Duchesne and C. Camiré. 2013. Etiology of a recent white spruce decline: Role of potassium deficiency, past disturbances, and climate change. Can. J. For. Res. 43(1): 66-77. doi: 10.1139/cjfr-2012-0344.

Paquette, A., J. Girard and D. Walsh. 2011. Deep planting has no short- or long-term effect on the survival and growth of white spruce, black spruce, and jack pine. North. J. Appl. For. 28(3): 146-151.

Perera, A.H., L.J. Buse and M.G. Weber (Eds). 2004. Emulating Natural Forest Landscape Disturbances: Concepts and Applications. Columbia University Press, New York, NY.

Pernot, C., N. Thiffault and A. DesRochers. 2019. Root system origin and structure influence planting shock of black spruce seedlings in boreal microsites. For. Ecol. Manage. 433: 594-605. doi: 10.1016/j.foreco.2018.11.043

Prévost, M. and D. Dumais. 2018. Long-term growth response of black spruce advance regeneration (layers), natural seedlings and planted seedlings to scarification: 25th year update. Scand. J. For. Res.1-11. doi: 10.1080/02827581.2018.1430250.

Quesnel, P.-O. and B. Côté. 2009. Prevalence of phosphorus, potassium, and calcium limitations in white spruce across Canada. J. Plant Nutr. 32(8): 1290-1305. doi: 10.1080/01904160903006002.

R Core Team. 2013. R: A language and environment for statistical computing. R Foundation for Statistical Computing, Vienna, Austria. Saucier, J.-P., P. Grondin and A. Robitaille. 2009. Cadre bioclimatique du Québec. In: Doucet R. (ed.) Manuel de foresterie, $2^{\text {nd }}$ ed. Ordre des ingénieurs forestiers du Québec. Éditions Multimondes. Québec, QC. Pp 186-205.

Senez-Gagnon, F., E. Thiffault, D. Paré, A. Achim and Y. Bergeron. 2018. Dynamics of detrital carbon pools following harvesting of a humid eastern Canadian balsam fir boreal forest. For. Ecol. Manage. 430: 33-42. doi: 10.1016/j.foreco.2018.07.044.
Simard, M.-J., Y. Bergeron and L. Sirois. 2003. Substrate and litterfall effects on conifer seedling survivorship in southern boreal stands of Canada. Can. J. For. Res. 33(4): 672-681. doi: 10.1139/X02-204.

Spilke J., H.-P. Piepho and X. Hu. 2005. A simulation study on tests of hypotheses and confidence intervals for fixed effects in mixed models for blocked experiments with missing data. J. Agric. Biol. Environ. Stat. 10(3): 374-389. doi: 10.1198/108571105X58199. St-Hilaire, G. 2011. L'enrichissement en épinette blanche à la forêt Montmorency, un traitement sylvicole intensif de restauration écosystémique dans la sapinière à bouleau blanc de l'est. M.Sc. Thesis, Faculté de foresterie, géographie et de géomatique, Université Laval, Québec, QC.

Thiffault, N. and R. Jobidon. 2006. How to shift unproductive Kalmia angustifolia - Rhododendron groenlandicum heath to productive conifer plantation. Can. J. For. Res. 36(10): 2364-2376. doi: 10.1139/x06-090.

Thiffault, N. and C. Ward. 2018. Mid- and long-term effects of stock type on the growth and yield of spruce seedlings in a non-herbicide scenario. Reforesta 6: 60-70. doi:10.21750/REFO R.6.05.58.

Thiffault, N., R. Jobidon and A.D. Munson. 2003. Performance and physiology of large containerized and bare-root spruce seedlings in relation to scarification and competition in Québec (Canada). Ann. For. Sci. 60(7): 645-655. doi: 10.1051/forest.

Thiffault, N., B.D. Titus and A.D. Munson. 2005. Silvicultural options to promote seedling establishment on Kalmia-Vacciniumdominated sites. Scand. J. For. Res. 20(2): 110-121. doi: 10.1080/ 02827580510008356 .

Thiffault, N., D. Chalifour and L. Bélanger. 2013. Enrichment planting of Picea glauca in boreal mixedwoods: Can localized site preparation enhance early seedling survival and growth? New For. 44(4): 533-546. doi: 10.1007/s11056-012-9361-5. 